Preliminary draft

\title{
Elite Dominance and Under-investment in Mass Education: Disparity in the Social Development of the Indian States, 1960-92
}

\author{
Sarmistha Pal \\ and \\ Sugata Ghosh \\ Department of Economics and Finance \\ Brunel University, UK.
}

\begin{abstract}
May 2006
Abstract: Literacy rates continue to be strikingly low among women and low caste population compared to the general population not only in any Indian state, but more so in the worst performing ones. The present paper offers an explanation of this disparate development in terms of the hypothesis of elite dominance that discriminates against women and low-caste people and systematically under-invests in mass education. We experiment with various indirect economic and political measures of elite dominance. Results based on the Indian state-level data for the period 1960-92 suggest that higher share of land held by the top $5 \%$ of the population (a) lowers spending on education as well as total developmental spending and (b) increases total non-developmental spending. (c) Greater proportion of minority representations (female and low caste members) in the ruling government however fails to have any perceptible impact on both development (including education) and non-development spending in our sample. (d) While underinvestment in education by the elite is supported by the lack of demand for education from the poorer population (who are often the marginalised people), greater initiatives of the state to enact land reform legislations enhance the spending on education.
\end{abstract}

Key words: Under-investment in education, Discrimination against female and low-caste population, Elite dominance, Persistence of elite dominance, Poverty, Land Reform.

JEL Code: I28, J15, H41, H52

\footnotetext{
* Corresponding author. Address: Department of Economics and Finance, Brunel University, West London UB8 3PH, UK. E-mail: sarmistha.pal@brunel.ac.uk. Fax. 44-1895-269770. We would like to thank Tim Besley and Berk Ozler for providing me the data, Indraneel Dasgupta and Manash Ranjan Gupta for very constructive comments on an earlier draft. We would also like to thank John Bennett, Parantap Basu, Jan Fidrmuc for helpful suggestions at an earlier stage of this paper. All errors are ours.
} 


\section{Elite Dominance and Under-investment in Mass Education: Disparity in the Social Development of the Indian States, 1960-92}

\section{INTRODUCTION}

Despite more than four decades of planning efforts with an emphasis on balanced regional development, inter- and intra-state disparities in literacy rates in India are striking. While adult literacy rate in Kerala was about 91\%, it was about half of that level (47\%) in Bihar in 2001. Gender inequity continues to remain a serious problem in all the states, though it is far worse in the worse-performing ones; while the gender gap is about $7 \%$ in Kerala, it is about $30 \%$ in Rajasthan and Bihar. Similarly, literacy rates among the Scheduled Castes (SC) and Scheduled Tribes (ST) are significantly lower than that for the general population. For example, literacy rate among the backward castes was only $37.41 \%$ in 1991 as compared to $52.21 \%$ for India as a whole; it was even lower among women belonging to the backward castes $(23.76 \%$ as compared to $39.29 \%$ for all Indian women).

Differences in the nature of politicians elected are a possible mechanism through which social structure could influence the allocation of public spending and thereby the availability/access to public goods and services in the Indian states. This is because it is harder for a democratically elected government to be unresponsive to the needs and values of their clientele, especially when the electorate is well informed and politically aware. The question however remains as to why the women and the low caste people in the Indian states, especially in the worst performing ones, may not obtain the full attention of the politicians in a democracy even when they have the numerical strength. 
When a country like Cameroon could more than double its rate of adult literacy in three decades after 1970 (from 30\% to $71 \%$ ), why a flourishing democracy like India that started in the 1970 s with $33 \%$ adult literate would still struggle with a rate of $57 \%$ in 2000 (with striking disparity in the literacy rates attained by female and low caste people as indicated above). In this context, the present paper explores the role of elite dominance on public spending on education in the Indian states. The paper contributes to the new institutional economics literature on the persistence of under-development and also to the growing literature on the political economy of the public goods provision in India.

Recent institutional literature (e.g., Acemoglu, Johnson and Robinson, 2001) suggests that poorer countries lack the institutions needed or have the wrong institutions for economic growth. Rajan and Zingales (2005), offer a parallel argument to suggest that underlying constituencies (with coexistence of self-perpetuating interest groups) rather than poor institutions may perpetuate this underdevelopment indulging in low investment in mass education. We shall, in this context, examine the hypothesis of elite dominance to explain underinvestment in mass education (a la Bourguignon and Verdier, 1999, among others) and also its persistence (a la Acemoglu, 2006) in the Indian context.

In doing so, the paper also contributes to some recent studies that highlighted the importance of the political process on the pattern of public spending at different levels of administrative units as well as on the provision of public goods/services in India. For example, Betancourt and Gleason (2000) highlight the importance of electoral participation, selectivity in the allocations against Muslims and Scheduled castes in the allotment of nurses, doctors and teachers to rural areas of the Indian districts. Banerjee and Somanathan (2001) suggest that more heterogeneous communities tend to be 
politically weaker and therefore are less likely to get the goods they want and more likely to get some of the inferior substitutes. Chattopadhyay and Dufflo (2004) argue that women councillors in elected village councils with reserved seats for women tend to invest more in drinking water, fuel and employment generating activities such as road construction (compared to those unreserved village councils).

Next turning to the studies pertaining to state-level spending on various accounts, Besley and Burgess (2001) highlight that media could play an important role to ensure government accountability to the electorate. Foster and Rosenzweig (2001) argue that while landowners would favour expenditure on irrigation, budget allocation would shift more towards labour-intensive road construction projects, as landless gain more participation with increasing decentralisation. Khemani in a series of papers $(2003,2004)$ highlights the effects of federal politics on earnings and spending of the states.

The present paper focuses on the role of 'elite dominance' to explain this disparate nature of social development over the period 1960-92 in sixteen major states in India. The issue of elite dominance, though pertinent in explaining this disparity more than fifty years after India's independence in 1947, remains much unexplored. It is argued here that the social, economic and political dominance of the elite in India is closely intertwined with the gender and the age-old institution of caste where the male members of the upper castes (at the expense of female and/or low caste members of the population) tend to enjoy better economic and political status at local, state and national levels. Although India's constitution forbids negative public discrimination of female and low caste people and introduces various ways to overcome the traditional barriers of gender and caste, gender and caste-based interaction/discrimination in all spheres of life 
is not uncommon still today and has not eroded the initial disadvantages of the female and low-caste people. The result is the striking disparity in the education indicators attained by these marginalized groups.

Our analysis of the state-level data ${ }^{1}$ from the selected states for the period 196092 suggests that greater land held by the top $5 \%$ of the population lowers spending on education while a greater proportion of minority representations in the ruling government fails to have any significant impact on education spending. ${ }^{2}$ We also find that states with more poverty rates have significantly lower spending while those with greater initiatives of land reform legislations have significantly higher spending on education. Unfortunately, gender, caste and class based politics perpetuates inequality. Spread of human capital could help to overcome the traditional disparities of caste, class and gender by allowing individuals to take advantage of the existing social opportunity, to make conscious and informed choice in voting as well as to induce direct political participation.

The paper is developed as follows. Section 2 investigates the concept and nature of elite dominance in India while Section 3 describes the data, explains the methodology and analyses the empirical results. The final section concludes.

\footnotetext{
${ }^{1}$ We choose this period to dissociate the effects of pro-market reforms on state spending on education. Interestingly, this period also marked the period prior to the introduction of the $73^{\text {rd }}$ amendment of the Constitution in 1993 (see discussion in section 2.2).

${ }^{2}$ Some may suggest that this result somewhat contrasts the Chattopadhyay and Duflo (2004) finding that elected women members of the village councils in West Bengal (after the introduction of reservation of women seats in 1993) have significant impact on certain types of investment including water supply, employment. Later we argue that our result pertaining to education spending at the state level is supported by the fact there is no significant association between election of these representatives and turnout of female and low-caste voters. In other words there is indirect evidence that there is no mandate for these elected members to serve the marginalised people.
} 


\section{CONCEPT AND NATURE OF ELITE DOMINANCE IN INDIA}

Given the pronounced unitary bias in the Indian federation, there are limits to the authority of the state government's spending ability as dictated by the union, state and concurrent lists of the Indian constitution. While the union government is involved in general state-level development especially with respect to the development of the core sectors, states have the primary responsibility for most social sectors including education, health, community and social services. Each state has an elected assembly headed by the chief minister (CM), who is in charge of formulating and implementing social development policies in the states. We label the particular state government ruled by the majority party in power as a 'political regime'. Political regimes may differ in terms of representation from and inclusion of different sections of population in their electoral base. This could result in differences in the democratic functioning of different regimes and could explain the variation in public spending on education in the Indian states.

\subsection{Concept of elite dominance}

Initial statistics quoted in the introduction suggest that women and low caste people are not only worse off compared to the general population when residing in any state of India, they are more so when residing in the poor performing states like Bihar, MP, Orissa, Rajasthan or UP. The question that arises here is why these minority groups fail to attract the attention of the democratically elected government despite their large numbers.

Recent development of the institutional economics and the political economy models could shed some light into the possible mechanisms in this respect. The dominance by an elite, which does not support human capital investment in the masses is 
a theme in several theoretical models including Bourguignon and Verdier (1999), Acemoglu and Robinson (1998), Galor and Moav (2000). In particular, Bourguignon and Verdier (1999) argue that the oligarchy will oppose widespread education because educated people are more likely to demand political power, which may undermine the dominance of the elite. This may result in a lower human capital outcome than otherwise. Similar argument is found in Rajan and Zingales (2005) who highlight the fact that education does give the poor the ability to take advantage of pro-market reforms and thus make them predisposed to further reform. Thus unlike Bourguignon and Verdier (1999) where education tends to increase the political participation of the poor, it is the fear of comprehensive reforms that makes the oligopolist in Rajan and Zingales (2005) to oppose education reforms. We, however, argue that empowerment of the marginalised non-elites (women and low caste through greater investment in education) not only improves their economic participation, but also enhances their political participation, directly (by demanding political power) and/or indirectly through making informed choice in a democratic election.

\subsection{Nature of elite dominance in India}

India is an interesting case in point where social, economic and political dominance of elite class is closely intertwined with the age-old institution of caste as well as the gender disparity. Although many other nations are characterized by social inequality, perhaps nowhere else in the world has inequality been so elaborately constructed as in the Indian institution of caste. Although India's constitution forbids negative public discrimination 
on the basis of caste, caste ranking and caste-based interaction have occurred for centuries and will continue to do so well into the foreseeable future, more in the countryside than in urban areas and more in the realms of kinship and marriage than in less personal interactions.

Castes are ranked, named, endogamous (in-marrying) groups, membership in which is achieved by birth. Many castes are traditionally associated with an occupation, such as high-ranking Brahmans (priests); middle-ranking farmer and artisan groups, such as potters, barbers, and carpenters; and very low-ranking "Untouchable" leatherworkers, butchers, launderers, and latrine cleaners. Although the term Untouchable appears in literature produced by these low-ranking castes, in the 1990s, many politically conscious members of these groups prefer to refer to themselves as Dalit, a Hindi word meaning oppressed or downtrodden. Since 1935 "Untouchables" have been known as Scheduled Castes, referring to their listing on government rosters, or schedules. Numerous groups usually called tribes (often referred to as Scheduled Tribes) are also integrated into the caste system to varying degrees. There is a close association between ritual rank on the caste hierarchy, ownership of both land and non-land assets (e.g., see Pal, 1994) and economic prosperity. Members of higher-ranking castes tend, on the whole, to be more prosperous than members of lower-ranking castes. Many lower-caste people lack any assets and live in conditions of great poverty and social disadvantage.

Within castes explicit standards are maintained. Transgressions may be dealt with by a village caste council, which meets periodically to adjudicate issues relevant to the caste. Such councils are usually formed of groups of elders, almost always males. Punishments such as fines and outcasting, either temporary or permanent, can be 
enforced. In rare cases, a person is excommunicated from the caste for gross infractions of caste rules. An example of such an infraction might be marrying or openly cohabiting with a mate of a caste lower than one's own; such behavior would usually result in the higher-caste person dropping to the status of the lower-caste person.

While women are guaranteed equality under the Indian constitution, legal protection has little effect in the face of prevailing (age-old) patriarchal traditions. Families are far less likely to educate girls than boys, and far more likely to pull them out of school, either to help out at home or from fear of violence; dowry may also have a role to play here. India has the largest population of non-school-going working girls. India's constitution guarantees free primary school education for both boys and girls up to age 14. While this goal has been repeatedly reconfirmed, its implementation has not been. Women work longer hours and their work is more arduous than men's, yet their work is unrecognized. Female infanticide and sex-selective abortions are additional forms of violence that reflect the devaluing of females in Indian society. Women lack the power to decide who they will marry, and are often married off as children. Legal loopholes are used to deny women inheritance rights. Dalit women have been the worst sufferers being suppressed by both men and women from all castes and class, resulting in their dismal performance (Seenarine, 1997). Thus surviving through a normal life cycle is a resourcepoor woman's greatest challenge.

\section{From social to political dominance of elite}

Social dominance of the upper caste elite could easily be translated into the political arena, especially in a democratic set-up. In the words of Key (1956), 'the nature of the 
workings of the government depends ultimately on the men who run it. The men we elect to office and the circumstances we create that affect their work determine the nature of the popular government.' Until the recent introduction of the elected village councils in 1993 (via $73^{\text {rd }}$ amendment of the Indian constitution) with reservation of seats for women and low caste members, there was no mechanism to prevent the dominance of traditional village elite in the village council, who could then easily go up the political ladder and may move to state assembly and national parliament. Thus, social and political elites are more likely to be male and come from the traditional upper caste in the Indian social hierarchy (especially in the pre-1993 period), exercising their political domination through state mechanism as well.

Our analysis focuses on the period $1960-92$, i.e., the period before the $73^{\text {rd }}$ amendment of the Indian Constitution commenced. ${ }^{3}$ This period has been marked by the predominance of the Indian National Congress (INC) regime in most states, especially until 1977, important exceptions being Tamil Nadu and Kerala where alternative regimes came to power from as early as 1967.

The social base for Congress had been the landed elite and the rural habitations they controlled resulting in a dominance of the upper class in Congress politics, especially in the first 30 years after independence. In the years after Independence untouchable support for Congress had clearly strengthened. From 1952 until 1989, with the exception of the post-Emergency election of 1977, Untouchables tended to function in both national and State elections as a 'vote bank' for Congress. Their vote for Congress was a vote for the party of government, a party that had committed itself to a program of

\footnotetext{
${ }^{3}$ Note that reservation of the seats for scheduled caste and scheduled tribe has been in place at various state and National elections. Following the $73^{\text {rd }}$ amendment of the Constitution, discussion is now under way about the reservation of seats for women at the state and national levels.
} 
action on Untouchability and poverty. While the Untouchables were a crucial Congress vote bank in a majority of individual States, they did not cling to Congress in regions where another party or movement rose to dominance. The major examples of long-term non-Congress dominance are West Bengal, Kerala, Tamil Nadu and Andhra Pradesh. Untouchables in the former two States have for a number of years had a strong identification with the Communist Party in its several divisions - in recent years predominantly with the dominant Communist Party of India (Marxist) (CPI(M)). In conrast, in both Tamil Nadu and Andhra, however, the Untouchables have not been wholly lost to Congress, despite the general popularity/predominance of the non-brahmin movement of DMK/ADMK in Tamil Nadu and TDP in Andhra.

Within Congress the importance of the Untouchable vote however did not translate itself into great influence for individual Untouchables in either the organisation of the party or the ministry. In particular, the building of the compensatory discrimination system arose more from the arithmetic of elections and the goodwill of sections of the elite than from the efforts of Dalit parliamentarians. Although a small number of state and national politicians have gained a measure of ministerial seniority, none has had either a long period at the apex of ministerial service or any substantial political base. Perhaps it is to be expected that a collection of castes distinguished by their overall subordination would not produce the highest crop of educated, experienced and generally talented politicians. Nevertheless issues of talent and preparation for public office among lowcaste politicians can scarcely constitute the primary explanation for the low representation of Untouchables at the highest political levels. There have also been persistent suggestions that Dalit politicians have not thrived within Congress if they have too strenuously promoted the cause of their own people. It remains an important truth that 
the ideological and social makeup of Congress has made it less than welcoming to highly assertive advocates of the Untouchable cause. Low social standing has also made individual Untouchable spokesmen relatively easy targets for political demolition. Untouchables have therefore tended to construct their political careers as dependants within factions led by high-caste politicians. It is impossible to think of a single example of a substantial multi-caste faction leader who is/was himself a Dalit.

Under-representation of women in the Indian politics is a well-known fact; what is more disappointing is how little has changed in this respect since the Independence. The candidates fielded by the various political parties are still dominantly male: women account for between 1-5 per cent of all candidates in the states under consideration. Very often these women come from elite upper caste background with some political tradition in the family or being close to a prominent male leader. However, their role in public decision making is rather negligible. They can rarely secure a position in the ministry and even when they do it, if ever, they will not be assigned any key role. Also more ambitious women members of the legislative assembly will choose to speak about issues not relating to women's affairs, but those relating to industry, trade, economy and international relations, where power and influence converge. Thus women's representation, though important on the grounds of social justice and legitimacy, does not naturally translate into improved representations of women's issues and interests.

Marginalised people everywhere have always aspired to build an egalitarian world. There has been a long tradition/history of resistance and creativity from below in different parts of India. Ranged against caste and Brahminism, this rational liberating tradition is to be found in the heterodoxies of various inclinations, particularly Buddhism, 
the movements of subaltern saint-poets, Sufism and Sikhism. This legacy was carried forward in modern India by, more than anybody else, Ambedkar (a dalit leader) and Gandhi. After independence, Ambedkar almost single-handedly wrote India's constitution, including key provisions barring caste-based discrimination. Nonetheless, discriminatory treatment of Dalits remains a factor in daily life, especially in villages, even in the twenty-first century. Despite their numerical strength, their voices are not heard through the ballot box. An important reason is that this group is more likely to be less educated and poorly informed and are generally less inclined to vote than richer and better educated citizens. Clearly average voter turnout (especially among women and low caste voters) has been significantly lower, especially in these worst performing states (see Table 3). In addition to lack of literacy and the general deprivation, the latter could also be a result of the criminalisation of politics (that resulted in many criminals being elected, Dréze and Sen, 1995), especially in some of the worst performing states like UP and Bihar, threatening/bribing the electorate (especially those less educated and marginalised and therefore vulnerable in a caste-based society) during election times to vote or not to vote in a certain way. With widespread illiteracy in these states many voters are not able to gain the full information necessary to make an informed choice and the judiciary too has often failed to uphold this fundamental right.

Let us in this context consider the case of politicization of teachers and teaching unions (Kingdon and Muzzamil, 2003) in the northern state of Uttar Pradesh (UP) that could illustrate how elite dominance is exercised in the education sector, especially when schools and other educational institutions receive government funds. UP is one of the 4 states in India that still has a legislative council - upper chamber of the Assembly- where 
teachers have guaranteed representations. The latter has resulted in influential political lobbying and pressure groups from within the system at a local level in the form of teachers' organisations. Education related legislation in UP has often been framed under immense pressure from teacher's organisation, especially at the primary and secondary level. Thus teachers in schools (as opposed to higher education) have been instrumental for local base for the political parties in the state. The latter has induced teachers' unions to indulge in regular strikes and other actions to promote their own interests (higher salary and job security) and rarely, if ever, for broader improvements of schooling and promotion of education in general. System of grants in aid from the government is however not linked with the qualitative performance of schools/number of working days. Forming a trade union is a legitimate worker right, but it makes it difficult for the government to deal impartially with teacher's demands. The natural consequence has been very poor performance of primary and secondary schools in the state as highlighted in existing literature (Dreze and Gazdar, 1997; Probe Report, 1999; Dreze and Kingdon, 2001).

Thus elite dominance could be rationalised in terms of a political economy outcome that entails benefits to both the political authorities and the elites. On the one hand, entrusting the governance of the state's education sector to a tiny elite (e.g., teacher's unions0, gives that elite huge advantages in political lobbying. Naturally these oligarchs lobby for weak regulations to facilitate private benefits of control. On the other hand, political insiders too see the benefits of cooperating with the oligarchs (especially during election times) as outweighing the costs, despite the detrimental effects on the masses in general. 
Once in place, elite dominance can be self-sustaining in the absence of some further shocks, inducing changes in endowment to break the vicious circle. ${ }^{4}$ In this respect, our analysis focuses on the role of (a) incidence of poverty and (b) land reform programmes, both of which could to some extent reflect the strength of demand (or lack of it). In particular, no one can deny the positive effect of land reform that has been successful elsewhere. For example, the rise of the gentry in Britain, the force behind the growing power of Parliament, accompanied the taming of the power of great lords and the Church by Henry VII and Henry VIII and the sale of their lands (Tawney, 1949). Similar events took place in Japan (Nelson, 1993) and Korea (Jeon and Kim, 2000) that led to successful land reforms accompanied by high growth in these countries. In fact introduction of land reforms and education reforms prior to the introduction of privatization and competitive reforms in a number of Asian economies laid the groundwork for faster growth. Secondly, in the Indian context no one can also deny the negative effect of poverty which could have been instrumental in supporting the elitist education policy that neglected the provision of basic education while highly subsidizing the higher education throughout India in the post-independent period. Persistence of poverty often changes the priorities of life where survival in the present period is more important than investment in education for long-term betterment of the quality of life.

\section{DATA AND EMPIRICAL ANALYSIS}

In this section we use the state-level data to examine the role of elite dominance on

\footnotetext{
${ }^{4}$ Rajan and Zingales (2005) in this respect discuss the positive of role of protestant religion, Nationalism and Communism to encourage mass education in different societies.
} 
changes in education spending over the term of the government in the selected states. Section 3.1 describes the data while the empirical analysis is performed and discussed in section 3.2.

\subsection{Data and sample characteristics}

The data set consists of state-level economic and political variables available from the World Bank (Ozler, Dutt and Ravallion, 1996), Besley and Burgess (2000) and Election Commission of India. It is not easy to isolate the effects of state politics from everything else going on in the country, especially since the launching of the Indian liberalisation programme in the early 1990s. Our analysis therefore focuses on the 1960-92 period, before the effects of liberalisation came to be realised.

The data points are the election years. The idea is that elected politicians will want to attain their targets by the time of the next election when the electorate decides whether to re-elect them. In most cases elections take place every five years though there can be an election before the next scheduled one if the government in power collapses. There can however be problems in the estimates if, for example, policies implemented in year four takes a further two years to complete so that the model will assign the effect to the next election cycle. While we need to be cautious in interpreting these results, one election cycle lag appears to be the best available option.

\subsection{Empirical analysis}

Our analysis is developed in three steps. First we examine the role of elite dominance on the changing share of state-level spending on education (as a share of state output). 
Secondly, we include the state-specific poverty rate to check if under-investment in education by the elite is actually supported by the demand for education in the selected states. Since INC has been the dominant political regime in most states during much of the study period, next we examine if predominance of the INC regime in the selected states is closely associated with economic and political elite dominance in our sample. Finally, we examine various accounts of government expenditure to find out if the elite has given priority to some accounts over education.

\section{Measures of elite dominance}

First step of our empirical analysis is to quantify the concept of elite dominance. In order to capture different dimensions of this complex issue, we generate two sets of indirect measures - one related to economic dominance of the elite while the other to their political dominance.

Land is both the main productive asset and the basis of survival of the majority in India still today. Thus land tenure is the foundation of social structure and political power. Very often there is also a close correspondence between caste and ownership of land in the Indian society; thus upper caste people often enjoy a much greater share of land while the low caste people turn out to be landless or marginal farmers. In the absence of a better indicator, we could form some idea of economic dominance of the elite, especially in the rural areas, from the distribution of land in these states. Table 2 shows the average percentage of total land area held by top 5\% and bottom $40 \%$ of the population and also the Gini coefficient in the distribution of land (LANDGINI) over 1960-92. Since there is very little variation in the Gini index of land distribution, we use 
the land held by the top 5\% of the population (TOP5) as an index of economic dominance of the elite.

We also try a composite index of different types of land reform legislations (CLR) in these states (see Besley and Burgess, 2000). Since land reforms are likely to have effects over time, we measure the extent of reform since the beginning of the data period by a cumulative variable that aggregates the number of legislative reforms. While crude, this could allow us to reasonably quantify the land reform measures. The underlying idea is that states where more land reform legislations were undertaken could be regarded as states with a more harmonious class relationship, thus alleviating the dominance of elite upper class. Table 2 clearly demonstrates the discrepancy in the distribution of land between top $20 \%$ and bottom $40 \%$ of the population in all the states; the extent of the discrepancy is much higher in some states including Punjab and Maharashtra than in others like J\&K, Assam or Kerala. Moderate degree of discrepancy persists in most other states though. There is also wide variation in the land reform activities across the states. In particular, the average values of this land reform legislation index appear to be relatively higher in Kerala, Tamil Nadu and West Bengal, states known for their successful social development programmes.

Further measures of economic elite dominance could be derived from the available information on distribution of consumer expenditure per capita (which also includes expenses on consumer durables). We have information on rural (GINI1) and urban Gini (GINI2) indices in the distribution of monthly per capita consumer expenditure; clearly higher values of rural and urban Gini indices would account for higher levels of dominance of an elite upper class in the state. The last two columns of 
Table 1 shows the inter-state variation in the average values of rural and urban Gini indices in the distribution of consumer expenditure per capita over 1960-92. Gini indices of consumer expenditure however fail to be significant in the regression exercise that we perform in section 3. Unfortunately, we do not have any alternative measure of the distribution of consumer expenditure like that (TOP5) available for the distribution of landholding.

Measures of political dominance of elite in the Indian states, on the other hand, may be captured from the composition of the ruling party in power. In particular, we include proportion of women and scheduled caste/tribe members of the legislative assembly in the ruling party, because these representatives of the marginalized people could make a difference in the formulation of policy and/or allocation of state spending to education in a democratic set-up. This information is summarized in Table 2 and highlights the marginal difference in the shares of women and low caste members of the assembly in the ruling government between INC and other non-INC regimes. In general INC shares of these seats won by the minority groups (women and SC/ST members) are higher in many states during 1960-92 (though only marginally), important exceptions being Kerala, West Bengal and Tamil Nadu (states where non-INC parties offered significant challenges to INC regimes for substantial period of time).

\section{Other explanatory variables}

In addition to various measures of Elite Dominance, we also control for some other possible covariates in our analysis. First, there is some recent literature that stresses the link between ethnic fractionalisation and the poor delivery of public services (e.g., see 
Alesina, Baqir and Easterly,1999). Banerjee and Somanathan (2001) have extended the idea of ethnic diversity for the provision of public goods in the Indian districts and suggest that more heterogeneous communities tend to be politically weaker and therefore are less likely to get the goods they want and are more likely to get some of the inferior substitutes.

Indian society has traditionally been multireligious (including majority Hindus ( $80 \%$ or above), Muslims, Christians, Sikhs, Buddhists and Jains), and multilingual (there are sixteen official languages in India). This social structure is further complicated by the prevailing caste system among the Hindus that distinguishes between upper caste (16\%), other backward castes (43.7), scheduled caste (15\%) and scheduled tribe $(7.5 \%)^{5}$, giving rise to a pluralistic society. This social structure did not pose any problem in the feudal politics that remained non-competitive where different groups were loyal to one or other dynasty. However with the consolidation of the British rule, Indian politics became competitive when different religious and linguistic groups began to compete with each other for the share of political power and government jobs. This trend continued and even in modern India - politicians continued to exploit this diversity and often catered to certain sections of the population, thus responding to their needs and disregarding the needs of others. Otherwise it is difficult for the ruling party to satisfy needs of all different factions and stay in power. A direct measure of ethnic fractionalisation would therefore be to construct a composite index of social heterogeneity (SOCHETY) from the proportion of the population belonging to various ethno-religious groups including upper caste Hindus, scheduled caste, scheduled tribes, Muslims, Jains, Buddhists, Christians,

${ }^{5}$ Source: Government of India, Report of the Backward Classes Commission (Mandal Commission Report), First Part, Vol. 1 (1980), p. 56. These figures are best estimates. The last caste census was taken in 1931. 
Sikhs and others. Inter-state variation in the average values of social heterogeneity measure is summarised in Table 3 for the study period 1960-92.

Another possible factor that could influence social spending at the state-level relates to the growing incidence of coalition governments in the Indian states. While the experience of coalition governments at the Centre goes back to 1977, it is a more recent trend in the assembly elections that have given rise to alliances between/among various political parties to form government at the state level. Existence of a coalition government may have important implications for the state spending patterns, since given the divergent agenda of the constituent parties, there may prevail a lack of coordination over budgetary decisions. This is because individual coalition partners in multi-party coalition governments may have distinct interests, which in turn would induce to protect its own share of the budget. Roubini and Sachs (1989) suggest that there is a tendency for larger budget deficits in countries characterized by a short average tenure of government and by the presence of many political parties in a ruling coalition. Haggard and Kaufman (1995) argue that fragmentation creates impediments for the co-ordination required to initiate and sustain policy changes. More cohesive systems are more likely to generate stable electoral and legislative support for economic reform. Echeverri-Gent (1998) however argued that the fear of losing power could in fact be considered the biggest strength of a weak coalition government. A downfall of the government would be a loss to every member of the coalition, which in turn may induce weak-coalition minority governments to undertake bold economic reforms. Dutta (1996) has examined the impact of coalition politics on some fiscal variables of the central government for the period 1967-93. We extend this argument to see if the coalition governments at the state level 
have positive (a la Echeverri-Gent, 1998) or negative (a la Haggard and Kaufman, 1995) effects on state-level spending on education.

\subsubsection{Determinants of Changes in Education Spending}

In this section, we determine the changing share of state spending on education (as a share of state output). Taking the share of particular spending in relation to state domestic product allows us to control for state's wealth. In particular, we consider the change in the value of the variable from the last election to be the dependent variable of interest. This differenced variable allows us to examine how the political regime would change the behaviour of the government in power while the level variable would simply reflect the correlation between political variables and the spending on education. Using the first difference of the state spending variable also allows us to reduce the possible problem of simultaneity arising from the inclusion of some of the explanatory variable described below.

Among the explanatory variables, we include the initial value of spending on education (EDUEXPY) and expect a negative sign on its coefficient; the latter would indicate convergence, if any, in the level of this spending among the states over time, conditional on values of other covariates. As indicated earlier, we also include measures of economic (TOP5 and CLR in two alternative specifications ${ }^{6}$ ) and political (PWOMRUL and PSCSTSRUL) dominance of elite. Note however that while proportion of land held by top 5\% of the population (TOP5) is a measure of dominance exercised by the landed elite, index of land reform legislations (CLR) as well as representation of

\footnotetext{
${ }^{6}$ As possible alternative measures of elite dominance, we also tried including the share of land held by top $10 \%$ and $20 \%$ of the population as well as Gini indices in the distribution of average monthly consumer expenditure per capita; but these variables never turned out to be significant. See discussion in section 3.2.
} 
women (PWOMRUL) and low caste (PSCSTRUL) in the ruling party really reflects the lack of dominance by the elite. It is expected that measures of elite dominance (or lack of it) would be associated with lower (higher) spending on education. Third, we include measures of ethnic fractionalisation $(\mathrm{SOCHETY})^{7}$ and expect that the coefficient of these measures would be negative in the determination of change in education spending. Finally we include a binary variable to indicate if the government in power is a coalition government (COALITION). The resultant effect could be positive, negative or may even be insignificant if the positive and negative effects outweigh each other (see discussion earlier in section 3.2).

Fixed effects panel data estimates are summarised in Tables 4A. A positive (negative) coefficient estimate would indicate an increase (decrease) in the share of education spending associated with an increase in the value of the explanatory variable. We show estimates for four specifications (columns 1-4) depending on the particular measure of elite dominance, with control for social heterogeneity and presence of coalition government, if any.

Interestingly, the initial level of education spending remains insignificant in all specifications. This would reflect the lack of convergence in social spending across the sample states and could perhaps be rationalised by the divergent agenda of ruling political regimes in these states. Secondly, ethnic heterogeneity and presence of coalition government both tend to lower spending on education. While the result for ethnic

\footnotetext{
${ }^{7} \mathrm{We}$ also tried including an indicator variable measuring if the state government is aligned to the government at the centre. INC has remained in power at the centre during most of this period, except 197780 (Janata Party rule), 1989-90 (National Front coalition government). Thus the binary variable takes a value 1 if the party in power at the state assembly is also the party in power at the centre and 0 otherwise. Alliance with the union could be important in determining both earning and spending patterns of the state (e.g., see Khemani, 2003). But the variable was never significant in explaining change in state level spending and that is why we exclude it from the final specification.
} 
heterogeneity is in line with Banerjee and Somanathan (2001) that for the coalition government contradicts Echiverri-Gent's argument. In contrast this supports that offered by Haggard and Kaufman (1995) so that the presence of a coalition government is associated with greater fragmentation and lack of cohesive policy at the state level, resulting in lower education spending in the subsequent years. Finally for given levels of ethnic heterogeneity and presence of coalition government, if any, effect of both measures of economic elite dominance turns out to be significant. For example, greater share of land among top 5\% of the population (indicating higher incidence of elite dominance) is associated with lower spending. Secondly, higher value of land reform legislations (associated with lower degree of elite dominance) results in significantly higher spending on education. Measures of political (non)dominance of elite however remain insignificant. For example, higher proportion of women and low caste members of the assembly in the ruling party does not significantly enhance education spending. However, when we add up the proportion of female and low caste members of the assembly in the ruling party, the variable becomes nearly significant, but only at around $10 \%$ level. The latter perhaps validates the general belief that higher representation of the marginalised people in the ruling government cannot by itself induce higher investment in education (see discussion in section 2$)^{8}$, especially if these members do not have any mandate to serve these marginalised people Taken together, there is some confirmation that higher degree of economic elite dominance (despite the difficulty of measuring it

\footnotetext{
${ }^{8}$ In order to explain this result, we examine if the winning seat in the assembly by female/low caste members is closely correlated with the turnout among female/low caste voters. If there is no such correlation it would not be necessary for these members to address the particular issue relevant for these communities. Indeed, our results show that there is no significant association between turnout among female/low caste voters and the election of women/low-caste members in the assembly, after controlling for initial illiteracy rate, ethnic heterogeneity of the state over the study period.
} 
precisely) is associated with significantly lower spending on education over the period 1960-92 while greater representation of marginalised groups in the ruling government (i.e., lower political dominance of elite) fails to generate any perceptible impact. In an attempt to explain this latter result, we examine if there is a direct correlation between election of women/SC/ST members in the ruling government of a particular state and the marginalised women/S/ST voters in our sample. Results shown in Table A1 in the Appendix tend to suggest that turnout of women or SC/ST voters does not significantly affect the proportion of these members of the assembly in the ruling government. This perhaps offers some indirect confirmation that women/SC/ST members of the assembly are not necessarily elected by the women/SC/ST voters - thus these members would not have any significant mandate to serve their cause so far as the education spending is concerned. Finally, we would like to highlight the result related to land reform legislations, which offers some hope to break the vicious cycle of elite dominance and persistence of underdevelopment through successful land reform programmes, even in the Indian states characterised by all-pervasive gender/caste divisions.

\subsubsection{Inclusion of demand}

The analysis of elite dominance is primarily supply-driven while no one can deny the importance of demand for education as well to explain the persistence of lack of educational attainment among the marginalised groups within a democratic set-up. There is a large literature on household demand for education in low-income regions, which highlights the significant role of gender, household income (Behrman and Knowles, 1999), parental (especially mother's) education (Glewwe, 1999), among others. Since, 
our study is conducted at the state-level, we consider the corresponding aggregate (statelevel) demand factors primarily related to access to endowment (or lack of it) of the households. In the absence of any better indicator, the analysis in this section includes poverty head count ratio that measures the lack of endowment/resources among poor households as the key demand factor driving the demand for basic education (or lack of it) ${ }^{9}$ at the state level. The underlying rationale is that survival in the current period is likely to be more crucial for the poor than the long-term prospect of improving income by investing in education today. Thus in addition to the variables included in Table 4A, we now augment each of these four models by including the poverty head count ratio. Estimates of these augmented models are presented in Table 4B. While the basic results discussed in section 3.2.2 remain unchanged, we get additional insight by including the poverty rate variable. In particular, there is confirmation that state spending on education is less in poorer states, even after controlling for all other factors including elite dominance. We thus argue that lower spending on education in the Indian states is not only a result of elite dominance, but is also driven by lower demand for basic education in states with higher poverty rates.

\subsubsection{Elite dominance and non-developmental Spending}

So far our analysis for the period 1960-92 suggests that the elite has an incentive to under-invest in mass education; the latter could also be supported by the lack of demand for education, especially among the poor and vulnerable marginalised groups. The question that naturally arises here is if the Elite have a preference for some other

\footnotetext{
${ }^{9}$ The correlation between household resources, income and wealth and educational attainment is well documented (e.g., see Behrman and Knowles, 1999). We thus focus on the effect of poverty rate that measures lack of resources/endowment on changes in education spending in our sample.
} 
expenditure account. Our investigation in this respect has focused on the trade-off between development and the non-development spending of the Indian states. Total government spending of the state governments in India is divided into development and non-development spending. Development spending includes spending on economic (e.g, agriculture and rural development) and social services (e.g., education, health, family welfare and other community services). Non-development spending in contrast includes spending on interest payments on past debts, expenditure on fiscal and administrative services, pensions and retirement benefits, non-planned expenditure on social security, welfare and food subsidies.

Between 1970 and early 1990s, total state government expenditure has grown substantially (five fold); growth in development spending has however slowed down dramatically: from $13 \%$ in the 1970 s to $7 \%$ in the 80 s and then to $1 \%$ in the 90 s. Within development spending account, social services grew the least in the 80s and the 90s. Sachs et al. (2000) argued that the resource constraints in state finances have been accentuated by a near stagnant tax-GDP ratio, a rising share of non-developmental outlay in the total expenditure, large volumes of hidden or implicit subsidies and increasing financial losses of state enterprises while a growing pressure on state finances has stemmed from the rising demand for public services. The critical problem in state finances is not only one of high levels of expenditure (relative to revenue mobilization), but also one of increasing distortions in the pattern of expenditure (i.e., higher growth of non-development vis-à-vis development spending). Following this trend in the allocation of state-level spending, especially towards non-developmental spending, we shall in this 
section explore if elite dominance is one of the explanations for the trend increase in nondevelopmental spending (as a share of state output).

As before, we ran four sets of regressions to explain changes in total (a) developmental and (b) non-developmental spending, depending on the measures of economic and political elite dominance. As with the estimates of the changes in education spending (see Table 4A and 4B), measures of political dominance variables turn out to be insignificant; so we do not show these results. Table $4 \mathrm{C}$ thus shows the two sets of fixed effects estimates for (a) and (b), using two alternative measures of economic elite dominance. We think these estimates offer some political economy explanations of the pattern of state spending away from development account and into non-development account. Indeed there is some confirmation that greater share of landholding among top $5 \%$ of the population is significantly and negatively associated with changes in developmental spending while it is positively associated with that in non-developmental spending in our sample. As before, the trend is just the opposite if states enact more land reform legislations. There is also significant evidence of divergent agenda among the Indian states as states with higher initial developmental and non-developmental spending continue to do so and there are no signs of catching up here.

Thus there is evidence of a close association between elite dominance and share of non-development spending in our sample; the latter is likely to be motivated by two possible and opposite mechanisms: increasing development (that includes education) as opposed to non-development spending is likely to dilute the power of the elite while increasing the share of the non-development spending could help maintain the group 
associated with the elite through offering subsidies and other non-planned benefits to the elite.

\subsubsection{Elite dominance and Political regime}

Finally, we explore if the measures of elite dominance is also significantly associated with the presence of dominant political regime in these states. Since INC has been the dominant political regime during our sample period, we focus on the determinants of the predominance of INC regime in the selected states. The latter is measured by a binary variable indicating if the ruling INC regime continued to run the government for a second term and is explained, among others, by some measure of elite dominance. Depending on the measure of elite dominance we have four different sets of results, as summarised in columns 1-4 of Table 5.

These estimates do suggest that land held by top $5 \%$ of the population significantly enhances the probability of Congress predominance while a higher value of land reform legislations index in a state tends to lower it. Measures of political dominance, as before, remain statistically insignificant either individually (column 3) or jointly (Column 4) for the sample period 1960-92.

This is not to say that the elite dominance will disappear with the decline of the Congress predominance in the 1990s. ${ }^{10}$ One example could perhaps validate this observation. Even the recent democratic revolution in North India in the mid-1990s that resulted in the election of a Dalit government led by Mayavati in UP for the first time in Indian history failed to have any perceptible impact on the literacy level in the state by the turn of the Millenium (see Table 1), despite bringing in formerly marginalized groups

\footnotetext{
${ }^{10}$ Note that this goes beyond the scope of our sample 1960-92.
} 
in the government. ${ }^{11}$ Unfortunately, there is no denial of the fact that even a government led by Dalit people would want to maintain its dominance and thus continue to underinvest in mass education to maintain its electoral base because educating them would dilute their long-term prospect of retaining power (through both economic and political participation of the poor). It is by now well-known that benefits from a large number of affirmative action policies and programmes targeted for the marginalised dalit in the Indian society have been monopolized by dalit men from a few sub-caste groups (Seenarine, 1997). The result would be persistence of disparity and under-development. This trend perhaps validates Acemoglu's (2006) prediction that even with changes in political regime, broad form of elite dominance (subjugation of the marginalized people in somewhat different form) continues to persist.

\section{CONCLUDING COMMENTS}

This paper attempts to explain the disparate nature of Indian social development, where female and low caste population are significantly worse off than the general population and more so when residing in one of the worse performing states in India. Persistence of low levels of education, especially among the marginalized groups (i.e., female and lowcaste people), is explained in terms of the hypothesis of elite dominance where the upper caste elite systematically adopts the policy of under-investment in mass education and the subjugation of the marginalized people persists in some form even with the change in political regime.

\footnotetext{
${ }^{11}$ This is in line with our regression results that higher proportion of female and low caste members of the assembly in the ruling government fails to boost education spending during 1960-92.
} 
Results based on the Indian state-level data for the period 1960-92 suggest that higher share of land held by the top 5\% of the population (a) lowers spending on education as well as total developmental spending and (b) increases total nondevelopmental spending; greater proportion of minority representations (female and low caste members) in the ruling government however fails to have any perceptible impact on both development and non-development spending in our sample. Our analysis also identifies two policies, namely, land reform and poverty alleviation to erode the initial disadvantage of the marginalised people: in particular, greater initiatives of the state to enact land reform legislations enhance the spending on education. States with larger proportion of the poor (who often belong to the marginalised women and low-caste people) however tend to be associated with under-investment in education because of a lack of demand for education among the poor.

Unfortunately, gender, caste and class based politics perpetuates inequality. Spread of human capital could help to overcome the traditional disparities of caste, class and gender, just as the removal of these inequalities helps the spread of human capital. Results of our analysis highlight the role of land reform and poverty alleviation to break the vicious circle of underdevelopment that offers endowment to improve the initial disadvantage of the marginalized people. This however is not an isolated process and needs to be implemented in conjunction with the education and financial sector reforms, enabling the marginalized people to take advantage of the on-going pro-market reforms as well as to consciously participate in the political process (and make an informed choice). Impartial judiciary has also a very important role to play to uphold this crucial 
fundamental right, especially in its fight against criminalisation of the political process.

We hope that future research will address some of these related issues.

\section{REFERENCES}

Acemoglou, D and J. Robinson. 1998. 'Why did the West Extend the Franchise? Democracy, Inequality and Growth in Historical Perspective', Working Paper, MIT Economics Department.

Acemoglu, D., J. A. Robinson and S. Johnson. 2001. 'The Colonial Origins of Comparative Development: An Empirical Investigation, American Economic Review, volume 91, pp. 1369-1401.

Acemoglu, D., J. A. Robinson and S. Johnson. 2002. 'Reversal of Fortune: Geography and Institutions in the Making of the Modern World Income Distribution, Quarterly Journal of Economics, volume 117, pp. 1231-1294.

Acemoglou, D and J. Robinson. 2006. 'Persistence of Power, Elite and Institutions', mimeo, MIT Departement of Economics.

Alesina, A. 1997. Macroeconomic Policy in a Two-Party System Repeated Game', Quarterly Journal of Economics, 101, pp. 651-678.

Alesina et al. 1999. Poltical Cycles and the Macroeconomy, Cambridge: MIT Press..

Alesina, A, R. Baqir and W. Easterly. 2000. 'Redistributive Government Employment', Journal of Urban Economics 2000.

Banerjee, A. and R. Somanathan. 2001. 'Caste, Community and Collective Action: The Political Economy of Public Goods Provision in India', mimeo, MIT Economics Department.

Behrman, J. R. and J.C. Knowles. 1999. 'Household Income and Child Schooling in Vietnam', The World Bank Economic Review, 13(2) pp. 211-56.

Besley, T. and R. Burgess. 2000. Land Reform, Poverty Reduction and Growth: Evidence from India', Quarterly Journal of Economics.

Besley, T. and R. Burgess. 2001. 'The Political Economy of Government Responsiveness: Theory and Evidence from India', Quarterly Journal of Economics.

Betancourt, R. and S. Gleason. 2000. 'The Allocation of Publicly Provided Goods to Rural Households in India: On some consequences of Caste, Religion and Democracy', 
World Development, 28(12), pp. 2169-82.

Bourguignon, F and T. Verdier. 2000. 'Oligarchy, Democracy, Inequality and Growth' Journal of Development Economics, 62(2) pp. 285-313.

Chattopadhyay, R and E. Duflo. (2004) Women as Policy Makers: Evidence from a India-Wide Randomized Policy Experiment', Econometrica, 72 (5), pp. 1409-43.

Chhibber, P. and I. Nooruddin. 2004. 'Do Party Systems Count? The number of parties and government performance in the Indian states', University of California Berkeley.

Chowdhury, A.R. 1993. Political Surfing over Economic Waves: parliamentary Election Timing in India', American Journal of Political Science 37, pp. 1110-1118.

Collier, P. 1998. 'The Political Economy of Ethnicity', paper presented at the Annual World Bank Conference on Development Economics, Washington DC.

Collier, P. and A. Garg. 1998. 'On Kin Groups and Wages in Africa', Oxford Bulletin of Economics and Statistics.

Das, N. P., Vinod K. Mishra, and P. K. Saha. 2001. 'Does community access affect the use of health and family welfare services in India, NFHS subject reports No. 18, East West Centre, USA.

De, Anuradha and J. Drèze. 1999. 'Public Report on Basic Education (PROBE) in India', Oxford University Press, USA.

Drèze, J. and A. Sen. 1995. India: Economic Development and Social Opportunity, Oxford: Oxford University Press.

Drèze, J and H. Gazdar. 1997. 'Uttar Pradesh: the burden of inertia' in Jean Dreze and Amartya Sen (edited) Indian Development : Selected Regional Perspectives, Clarendon Press, Oxford.

Drèze, J. and G. Kingdon, G. 2001. "School Participation in Rural India", Review of Development Economics, 5, No. 1: 1-33.

Dutta, B. 1996. 'Coalition Governments and Fiscal Policies in India', mimeo, ISI, Delhi.

Echeverri-Gent, J. 1998. Weak State, Strong Reforms? Globalization, Partisan Competition and the Paradox of India's Economic Reform', Paper presented at the 1998 Annual Meeting of the American Political Science Association, Boston MA.

Fedderson, T. 1992. A Voting Model Implying Duvergers Law and Positive Turnout', American Journal of Political Science, 36, pp. 938-62. 
Foster, A. and M. Rosenzweig. 2001. 'Democratization, Decentralization and the Distribution of Local Public Goods in a Poor Rural Economy', Brown Manuscript.

Galor, O. and O. Moav. 2000. 'Das Human Kapital', Brown University mimeo.

Ghosh, S. and S. Pal. 2004. 'The Effect of Inequality on Growth: Theory and Evidence from the Indian States', Review of Development Economics, 8(1), pp. 164-77.

Glewwe, P. 1999. 'Why does mother schooling raise child health in developing countries: Evdience from Morocco', Journal of Human Resources 34(1), 124-59.

Haggard, S. and R.R. Kaufman. 1995. 'The Political Economy of Democratic Transitions', Princeton University Press, Princeton.

Harriss, J. 1999. 'Comparing Political Regimes Across Indian States: A Preliminary Essay', Economic and Political Weekly, November 27.

Jeon, Yoong-Deok and Young-Yong Kim. 2000. 'Land Reform, Income Distribution and Agricultural Production in Korea', Economic Development and Cultural Change, 48(2), pp. 253-68.

Khemani, S. 2003. 'Partisan politics and intergovernmental transfers in India', World Bank Policy Research Working Paper , 3016.

Khemani, S. 2004. 'Political cycles in a developing economy - effect of elections in Indian States', Journal of Development Economics.

Kingdon, G. and M. Muzammil. 2003. The Political Economy of Education in India: Teacher Politics in Uttar Pradesh, Oxford University Press, Delhi.

McKay, A. and S. Pal. 2004. 'Relationships between Household Consumption and Inequality in Indian States', Journal of Development Studies, 40(5), pp. 65-90.

Nelson, G. 1993. 'Agricultural Policy Reform in Eastern Europe: Disussion', American Journal of Agricultural Economics 75(3), pp. 857-59.

Ozler, Berk, Gaurav Datt, and Martin Ravallion. 1996. "A Database on Poverty and Growth in India," Policy Research Department, The World Bank.

Pal, S. 1994. 'Choice of Regular and Casual Labour Contracts: A Theoretical and Empirical Analysis', Unpublished $\mathrm{PhD}$ dissertation, London School of Economics.

Public Affairs Centre. 2002. 'The State of India's Public Services: Benchmarks for the New Millennium’, PAC Manuscript.

Rajan, R. and L. Zingales. 2005. 'The persistence of underdevelopment: Institutions, Human Capital, or Constituencies?', NBER working paper No. 12093, December. 
Roubini, N. and J.D. Sachs. 1989. 'Political and Economic Determinants of Budget Deficits in Industrial Democracies', European Economic Review, 33, p. 903-38.

Roy, T.K. and B. Paswan. 1995. 'Demand for Family Planning Among Scheduled Castes and Scheduled Tribes' in: The Family Welfare Programme in India. Edited by Hari Mohan Mathur. Vikas Publishing.

Sahs, J., A., Varshney, N. Bajpai. 2000. 'India in An Era of Economic Reform'(edited), Oxford University Press, US.

Seenarine, M. 1997. 'Dalit Female Education and Empowerment' Dalit International Newsletter, 2 (1), February 1997. Waterford, CT. 
Table 1. Characterisation of economic elite dominance, 1960-92

\begin{tabular}{|l|l|l|l|l|l|l|l|l|}
\hline & \multicolumn{2}{|l|}{$\begin{array}{l}\text { Literacy } \\
\text { rates }\end{array}$} & \multicolumn{2}{l|}{$\begin{array}{l}\text { \% of land held } \\
\text { by }\end{array}$} & & & \multicolumn{2}{l|}{$\begin{array}{l}\text { Gini index in } \\
\text { consumption }\end{array}$} \\
\hline State & $\mathbf{1 9 9 1}$ & $\mathbf{2 0 0 1}$ & $\begin{array}{l}\text { top } \\
\mathbf{5 \%}\end{array}$ & $\begin{array}{l}\text { bottom } \\
\mathbf{4 0 \%}\end{array}$ & $\begin{array}{l}\text { Gini } \\
\text { index in } \\
\text { land } \\
\text { distribn }\end{array}$ & $\begin{array}{l}\text { Cumulative } \\
\text { land } \\
\text { reform } \\
\text { legislation } \\
\text { index }\end{array}$ & Rural & Urban \\
\hline AP & 44.10 & 61.1 & 41.4 & 0.79 & 0.74 & 1.58 & 29.6 & 32.4 \\
\hline Assam & 52.90 & 64.3 & 25.6 & 2.53 & 0.60 & 2.18 & 20.7 & 31.5 \\
\hline Bihar & 38.50 & 47.5 & 34.6 & 1.76 & 0.68 & 4.61 & 27.2 & 34.6 \\
\hline Gujarat & 61.30 & 70.0 & 31.7 & 0.73 & 0.69 & 3.33 & 27.6 & 30.2 \\
\hline Haryana & 55.80 & 68.6 & - & - & - & - & 27.1 & 30.8 \\
\hline J\&K & - & 54.5 & 21.5 & 10.43 & 0.49 & 1.45 & 24.3 & 26.9 \\
\hline Karnataka & 56.00 & 67.0 & 32.8 & 1.29 & 0.67 & 2.55 & 29.3 & 34.5 \\
\hline Kerala & 89.80 & 90.9 & 42.3 & 7.95 & 0.69 & 5.64 & 32.6 & 40.6 \\
\hline MP & 44.20 & 64.1 & 29.7 & 2.61 & 0.63 & 3 & 31.0 & 35.6 \\
\hline Maharastra & 64.90 & 77.3 & 33.2 & 0.58 & 0.70 & 1.97 & 31.8 & 37.2 \\
\hline Orissa & 49.10 & 63.6 & 31.3 & 2.26 & 0.64 & 5.33 & 27.7 & 33.1 \\
\hline Punjab & 58.50 & 69.9 & 37.1 & - & 0.74 & 0.64 & 31.7 & 33.4 \\
\hline Rajasthan & 38.60 & 61.0 & 33.3 & 4.65 & 0.63 & 1 & 36.0 & 32.5 \\
\hline Tamil N & 62.70 & 73.5 & 39.6 & 0.60 & 0.74 & 4.36 & 29.9 & 35.4 \\
\hline UP & 41.60 & 57.4 & 29.8 & 3.05 & 0.62 & 2.48 & 28.6 & 32.5 \\
\hline $\begin{array}{l}\text { West } \\
\text { Bengal }\end{array}$ & 57.70 & 69.2 & 31.6 & 1.32 & 0.67 & 5.18 & 26.7 & 33.1 \\
\hline
\end{tabular}


Table 2. Characterisation of political elite dominance, 1960-92

\begin{tabular}{|l|l|l|l|l|l|l|}
\hline & $\begin{array}{l}\text { \% of women among } \\
\text { all candidates in the } \\
\text { assembly elections }\end{array}$ & $\begin{array}{l}\text { \% of women among } \\
\text { all mlas in the ruling } \\
\text { party }\end{array}$ & $\begin{array}{l}\text { \% of sc/st members } \\
\text { among all mlas in the } \\
\text { ruling party }\end{array}$ \\
\hline & $\begin{array}{l}\text { All } \\
\text { regimes }\end{array}$ & $\begin{array}{l}\text { INC } \\
\text { regime }\end{array}$ & $\begin{array}{l}\text { All } \\
\text { regimes }\end{array}$ & $\begin{array}{l}\text { INC } \\
\text { regime }\end{array}$ & $\begin{array}{l}\text { All } \\
\text { regimes }\end{array}$ & $\begin{array}{l}\text { INC } \\
\text { regime }\end{array}$ \\
\hline AP & 3.4 & $\mathbf{3 . 4}$ & 4.00 & $\mathbf{4 . 3}$ & 22.2 & $\mathbf{2 5 . 8}$ \\
\hline Assam & 2.0 & $\mathbf{1 . 6}$ & 3.1 & $\mathbf{4 . 4}$ & 24.6 & $\mathbf{2 5 . 4}$ \\
\hline Bihar & 2.4 & $\mathbf{2 . 5}$ & 4.7 & $\mathbf{5 . 8}$ & 22.7 & $\mathbf{2 3 . 8}$ \\
\hline Gujarat & 2.4 & $\mathbf{2 . 3}$ & 6.8 & $\mathbf{7 . 7}$ & 37.0 & $\mathbf{3 6 . 1}$ \\
\hline Haryana & 2.6 & $\mathbf{2 . 5}$ & 7.8 & $\mathbf{9 . 4}$ & 23.0 & $\mathbf{2 0 . 1}$ \\
\hline J\&K & 1.3 & $\mathbf{1 . 0}$ & 1.7 & $\mathbf{3 . 5}$ & 3.9 & $\mathbf{6 . 9 3}$ \\
\hline Karnataka & 3.3 & $\mathbf{3 . 0}$ & 5.2 & $\mathbf{6 . 5}$ & 21.2 & $\mathbf{2 2 . 5}$ \\
\hline Kerala & 2.2 & $\mathbf{2 . 1}$ & 1.5 & $\mathbf{0}$ & 6.3 & $\mathbf{5 . 7}$ \\
\hline MP & 2.3 & $\mathbf{2 . 3}$ & 6.7 & $\mathbf{9 . 5}$ & 46.8 & $\mathbf{4 9 . 8}$ \\
\hline Maharastra & 3.2 & $\mathbf{3 . 3}$ & 5.8 & $\mathbf{6 . 2}$ & 18.0 & $\mathbf{2 0 . 3}$ \\
\hline Orissa & 2.5 & $\mathbf{2 . 3}$ & 4.4 & $\mathbf{4 . 7}$ & 47.1 & $\mathbf{5 4 . 6}$ \\
\hline Punjab & 2.8 & $\mathbf{2 . 7}$ & 5.0 & $\mathbf{8 . 2}$ & 23.6 & $\mathbf{2 4 . 8}$ \\
\hline Rajasthan & 2.0 & $\mathbf{1 . 7}$ & 6.5 & $\mathbf{7 . 1}$ & 35.6 & $\mathbf{3 4 . 6}$ \\
\hline Tamil N & 2.1 & $\mathbf{1 . 2}$ & 4.6 & $\mathbf{3 . 4}$ & 21.2 & $\mathbf{2 2 . 8}$ \\
\hline UP & 2.3 & $\mathbf{2 . 4}$ & 6.0 & $\mathbf{8 . 1}$ & 24.4 & $\mathbf{2 4 . 4}$ \\
\hline West & 2.1 & $\mathbf{1 . 7}$ & 4.0 & $\mathbf{3 . 5}$ & 28.0 & $\mathbf{2 4 . 0}$ \\
Bengal & & & & & & \\
\hline
\end{tabular}


Table 3. Presence of coalition government, degree of ethnic heterogeneity and voter turnout in the selected states, 1960-92

\begin{tabular}{|l|l|l|l|l|l|}
\hline & & & \multicolumn{3}{|l|}{ Voter turnout (\%) } \\
\hline State & $\begin{array}{l}\text { Coalition } \\
\text { government }\end{array}$ & $\begin{array}{l}\text { Ethnic } \\
\text { Heterogeneity }\end{array}$ & SC/ST & Women & All \\
\hline AP & 0.00 & 0.47 & 59.2 & 64.0 & 68.3 \\
\hline Assam & 0.00 & 0.64 & 57.5 & 56.0 & 61.3 \\
\hline Bihar & 0.25 & 0.70 & 41.7 & 42.5 & 53.5 \\
\hline Gujarat & 0.29 & 0.48 & 49.0 & 50.5 & 55.6 \\
\hline Haryana & 0.25 & 0.46 & 31.2 & 64.2 & 67.4 \\
\hline J\&K & 0.00 & 0.26 & 31.7 & 51.2 & 69.0 \\
\hline Karnataka & 0.00 & 0.51 & 62.9 & 62.6 & 67.2 \\
\hline Kerala & 0.78 & 0.67 & 70.3 & 65.8 & 75.6 \\
\hline MP & 0.14 & 0.53 & 43.3 & 40.9 & 51.2 \\
\hline Maharashtra & 0.29 & 0.46 & 51.9 & 57.0 & 61.2 \\
\hline Orissa & 0.25 & 0.56 & 38.4 & 35.0 & 46.7 \\
\hline Punjab & 0.25 & 0.55 & 31.4 & 65.3 & 67.9 \\
\hline Rajasthan & 0.14 & 0.54 & 48.6 & 41.0 & 55.4 \\
\hline $\begin{array}{l}\text { Tamil } \\
\text { Nadu }\end{array}$ & 0.25 & 0.44 & 63.3 & 66.1 & 69.7 \\
\hline UP & 0.11 & 0.63 & 35.9 & 43.6 & 50.5 \\
\hline $\begin{array}{l}\text { West } \\
\text { Bengal }\end{array}$ & 0.88 & 0.66 & 64.2 & 57.8 & 67.3 \\
\hline
\end{tabular}


Table 4A. Effects of Elite Dominance: Fixed Effects Estimates of Changes in Education Spending, 1960-92

\begin{tabular}{|c|c|c|c|c|}
\hline & \multicolumn{4}{|c|}{ Change in Education spending (as a share of output) } \\
\hline Variable & $\begin{array}{l}\text { (1) Est. } \\
\text { (T-stat) }\end{array}$ & $\begin{array}{l}\text { (2) Est. } \\
\text { (T-stat) }\end{array}$ & $\begin{array}{l}\text { (3) Est. } \\
\text { (T-stat) }\end{array}$ & $\begin{array}{l}\text { (4) Est. } \\
\text { (T-stat) }\end{array}$ \\
\hline $\begin{array}{lc}\begin{array}{l}\text { Initial share } \\
\text { education spending }\end{array} & \text { of } \\
\end{array}$ & $0.09(0.156)$ & $0.05(0.780)$ & $-0.02(0.304)$ & $0.03(0.455)$ \\
\hline $\begin{array}{l}\text { Land held by top } 5 \% \text { of } \\
\text { the population }\end{array}$ & $\begin{array}{l}-0.007 \\
(1.834)^{*}\end{array}$ & - & - & \\
\hline $\begin{array}{l}\text { Land reform legislation } \\
\text { index }\end{array}$ & - & $\begin{array}{l}0.008 \\
(2.468)^{* * *}\end{array}$ & - & \\
\hline $\begin{array}{l}\text { Proportion of women } \\
\text { MLA in ruling party }\end{array}$ & - & - & $0.002(1.217)$ & - \\
\hline $\begin{array}{l}\text { Proportion of SC/ST } \\
\text { MLAs in ruling party }\end{array}$ & - & - & $0.006(0.784)$ & - \\
\hline $\begin{array}{l}\text { Proportion of women } \\
\text { and SC/ST MLAs in } \\
\text { ruling party }\end{array}$ & - & - & - & $0.002(1.622)$ \\
\hline Social heterogeneity & $\begin{array}{l}-0.02 \\
(4.577) * *\end{array}$ & $-0.02(4.881)^{* *}$ & $\begin{array}{l}-0.02 \\
(4.338) * *\end{array}$ & $-0.02(4.314)^{* *}$ \\
\hline Coalition government & $\begin{array}{l}-0.003 \\
(1.987)^{*}\end{array}$ & $-0.003(1.984) *$ & $\begin{array}{l}-0.002 \\
(1.648)^{*}\end{array}$ & $-0.003(1.657)^{*}$ \\
\hline $\mathrm{R}^{2}$ & 0.56 & 0.57 & 0.56 & 0.56 \\
\hline F-Stat & $5.67 * *$ & $5.99 * *$ & $5.31 * *$ & $5.59 * *$ \\
\hline Nobs. & 113 & 113 & 119 & 119 \\
\hline
\end{tabular}

Note: '*' denotes significance at $10 \%$ or lower level while '**' denotes that at $1 \%$ or lower level. 
Table 4B. Effects of elite dominance with control for demand:

Fixed Effects Estimates of Changes in Education Spending, 1960-92

\begin{tabular}{|c|c|c|c|c|}
\hline & \multicolumn{4}{|c|}{ Change in Education spending (as a share of output) } \\
\hline Variable & $\begin{array}{l}\text { (1) Est. } \\
\text { (T-stat) }\end{array}$ & \begin{tabular}{|l} 
(2) Est. \\
(T-stat)
\end{tabular} & \begin{tabular}{|l|} 
(3) Est. \\
(T-stat)
\end{tabular} & \begin{tabular}{|l|} 
(4) Est. \\
(T-stat)
\end{tabular} \\
\hline $\begin{array}{lc}\text { Initial share } & \text { of } \\
\text { education spending }\end{array}$ & $0.11(1.846)^{*}$ & $0.13(2.018)^{*}$ & $\begin{array}{l}0.11 \\
(1.717)^{* * *}\end{array}$ & $0.10(1.621)$ \\
\hline $\begin{array}{l}\text { Land held by top 5\% of } \\
\text { the population }\end{array}$ & $\begin{array}{l}-0.004 \\
(1.930)^{*}\end{array}$ & & - & - \\
\hline $\begin{array}{l}\text { Land reform legislation } \\
\text { index }\end{array}$ & - & $0.004(1.632)^{*}$ & - & - \\
\hline $\begin{array}{l}\text { Proportion of women } \\
\text { MLA in ruling party }\end{array}$ & - & - & $\begin{array}{l}-0.0002 \\
(0.134)\end{array}$ & - \\
\hline $\begin{array}{l}\text { Proportion of } \mathrm{SC} / \mathrm{ST} \\
\text { MLAs in ruling party }\end{array}$ & - & - & $0.005(0.772)$ & - \\
\hline $\begin{array}{l}\text { Proportion of women } \\
\text { and SC/ST MLAs in } \\
\text { ruling party }\end{array}$ & - & - & & $0.0002(1.143)$ \\
\hline Social heterogeneity & $\begin{array}{l}-0.03 \\
(5.628)^{* *}\end{array}$ & $-0.03(5.687)$ & $\begin{array}{l}-0.03 \\
(5.512)^{* *}\end{array}$ & $-0.03(5.494)^{* *}$ \\
\hline Coalition government & $\begin{array}{l}-0.003 \\
(1.682)^{*}\end{array}$ & $-0.003(1.689)^{*}$ & $-0.002(1.280)$ & $-0.003(1.950)^{*}$ \\
\hline $\begin{array}{l}\text { Poverty head count } \\
\text { ratio }\end{array}$ & $\begin{array}{l}-0.0003 \\
(3.950)^{* * *}\end{array}$ & $\begin{array}{l}-0.0003 \\
(3.635)^{* *}\end{array}$ & $\begin{array}{l}-0.0003 \\
(3.880)^{* *}\end{array}$ & $\begin{array}{l}-0.0003 \\
(3.898)^{* *}\end{array}$ \\
\hline $\mathrm{R}^{2}$ & 0.63 & 0.63 & 0.63 & 0.62 \\
\hline F-Stat & $7.10 * *$ & $7.17 * *$ & $6.62 * *$ & $6.92 * *$ \\
\hline Nobs. & 113 & 113 & 119 & 119 \\
\hline
\end{tabular}

Note: '*' denotes significance at $10 \%$ or lower level while '**' denotes that at $1 \%$ or lower level. 
Table 4C. Effects of Elite Dominance: Fixed Effects Estimates of Changes in NonDevelopmental Spending, 1960-92

\begin{tabular}{|l|l|l|l|l|}
\hline & \multicolumn{2}{|l|}{$\begin{array}{l}\text { Change in non-developmental } \\
\text { spending (as a share of output) }\end{array}$} & $\begin{array}{l}\text { Change in developmental } \\
\text { spending (as a share of output) }\end{array}$ \\
\hline Variable & $\begin{array}{l}\text { (1) Est. } \\
\text { (T-stat) }\end{array}$ & $\begin{array}{l}\text { (2) Est. } \\
\text { (T-stat) }\end{array}$ & $\begin{array}{l}\text { (3) Est. } \\
\text { (T-stat) }\end{array}$ & $\begin{array}{l}\text { (4) Est. } \\
\text { (T-stat) }\end{array}$ \\
\hline $\begin{array}{l}\text { Initial share of non- } \\
\text { development spending }\end{array}$ & $\begin{array}{l}0.69 \\
(9.421)^{* *}\end{array}$ & $0.69(9.190)^{* *}$ & $\begin{array}{l}0.51 \\
(6.070)^{* *}\end{array}$ & $0.58(6.893)^{* *}$ \\
\hline $\begin{array}{l}\text { Land held by top 5\% of } \\
\text { the population }\end{array}$ & $\begin{array}{l}0.009 \\
(1.713)^{*}\end{array}$ & - & $\begin{array}{l}-0.004 \\
(1.721)^{*}\end{array}$ & - \\
\hline $\begin{array}{l}\text { Land reform legislation } \\
\text { index }\end{array}$ & - & $-0.005(1.720)^{*}$ & - & $0.006(3.429)^{* *}$ \\
\hline Social heterogeneity & $-0.07(1.418)$ & $-0.07(1.202)$ & $\begin{array}{l}-0.13 \\
(3.997)^{* *}\end{array}$ & $-0.15(4.691)^{* *}$ \\
\hline Coalition government & $-0.008(1.417)$ & $-0.008(1.379)$ & $-0.01(1.718)^{*}$ & $-0.01(1.913)^{*}$ \\
\hline$R^{2}$ & 0.56 & 0.55 & 0.41 & 0.45 \\
\hline F-Stat & $5.71^{* *}$ & $5.56^{* *}$ & $4.32^{* *}$ & $4.98^{* *}$ \\
\hline Nobs. & 113 & 113 & 119 & 119 \\
\hline
\end{tabular}

Note: '*' denotes significance at $10 \%$ or lower level while '**' denotes that at $1 \%$ or lower level. 
Table 5. Fixed Effects Panel Probit Estimates of Congress Predominance

\begin{tabular}{|c|c|c|c|c|}
\hline Lagged variables & (1) & (2) & (3) & (4) \\
\hline $\begin{array}{l}\text { Land held by top } \\
5 \% \text { of the } \\
\text { population }\end{array}$ & $0.24(1.983)^{*}$ & & - & - \\
\hline $\begin{array}{l}\text { Land reform } \\
\text { legislation index }\end{array}$ & - & $-0.35(2.367)^{*}$ & - & - \\
\hline $\begin{array}{ll}\text { Proportion } & \text { of } \\
\text { women MLA in } \\
\text { ruling party }\end{array}$ & - & - & $0.57(1.491)$ & - \\
\hline $\begin{array}{l}\text { Proportion of } \\
\text { SC/ST MLAs in } \\
\text { ruling party }\end{array}$ & - & - & $-0.74(0.453)$ & - \\
\hline $\begin{array}{l}\text { Proportion of } \\
\text { women and } \\
\text { SC/ST MLAs in } \\
\text { ruling party }\end{array}$ & - & - & - & $0.51(1.417)$ \\
\hline $\begin{array}{l}\text { Social } \\
\text { heterogeneity }\end{array}$ & $0.4(1.204)$ & $0.21(1.774)$ & $0.81(0.758)$ & $0.78(0.737)$ \\
\hline $\begin{array}{l}\text { Coalition } \\
\text { government }\end{array}$ & $-0.91(2.036)^{*}$ & $-0.94(2.111)^{*}$ & $-0.78(1.646)^{*}$ & $-0.73(1.679)^{*}$ \\
\hline Log-L & -54.00865 & -51.086 & -54.89061 & -55.0620 \\
\hline Log-L0 & -68.68864 & -68.68864 & -68.68864 & -68.68864 \\
\hline \multicolumn{5}{|l|}{ LR (chi-square) } \\
\hline Nobs. & 121 & 121 & 121 & 121 \\
\hline
\end{tabular}

Note: '*' denotes significance at $10 \%$ or lower level while '**' denotes that at $1 \%$ or lower level. 


\section{APPENDIX}

Table A1. An explanation of the insignificance of the political dominance variables: Fixed effects estimates of proportion of elected women/SCST members in the ruling party

\begin{tabular}{|l|l|l|l|l|}
\hline Variables & $\begin{array}{l}\text { (1) Proportion } \\
\text { of women MLA } \\
\text { in the ruling } \\
\text { party }\end{array}$ & $\begin{array}{l}\text { (2) Proportion } \\
\text { of women MLA } \\
\text { in the ruling } \\
\text { party }\end{array}$ & $\begin{array}{l}\text { (3) Proportion } \\
\text { of SC/ST MLA } \\
\text { in the ruling } \\
\text { party }\end{array}$ & $\begin{array}{l}\text { (4) Proportion of } \\
\text { SC/ST MLA in } \\
\text { the ruling party }\end{array}$ \\
\hline $\begin{array}{l}\text { Women voters' } \\
\text { turnout }\end{array}$ & $-0.02(0.589)$ & $0.01(0.236)$ & - & - \\
\hline $\begin{array}{l}\text { SC/ST voters' } \\
\text { turnout }\end{array}$ & - & - & $-0.008(0.719)$ & $-0.002(1.337)$ \\
\hline Illiteracy rate & - & $-0.13(1.832)^{*}$ & - & $-0.52(2.583)^{* *}$ \\
\hline $\begin{array}{l}\text { Social } \\
\text { heterogeneity }\end{array}$ & - & $-0.27(0.373)$ & - & $-0.58(0.369)$ \\
\hline $\begin{array}{l}\text { Coalition } \\
\text { government }\end{array}$ & - & $-0.23(1.758)^{*}$ & - & $-0.09(3.656)^{* *}$ \\
\hline F & $4.96^{* *}$ & $4.83^{* *}$ & $9.23^{* *}$ & $8.61^{* *}$ \\
\hline $\mathrm{R}^{2}$ & 0.53 & \multicolumn{1}{|c|}{0.56} & 0.59 & 0.66 \\
\hline Nobs. & 121 & 121 & 121 & 121 \\
\hline
\end{tabular}

Note: '*' denotes significance at $10 \%$ or lower level while '**' denotes that at $1 \%$ or lower level. 
